\title{
Authenticity: A Macromarketing Perspective
}

\author{
Djavlonbek Kadirov', Richard J. Varey ${ }^{2}$, and Ben Wooliscroft ${ }^{3}$
}

\begin{abstract}
This investigation argues that authenticity is inherently a macromarketing concept that is linked to how marketers and consumers view themselves and their own status in society. We show that authenticity refers to the marketer's marketplace condition (mindset) that can be best described as sincere concern for another. We argue that micromarketing as a general phenomenon is rooted in inauthenticity due to the fact that micromarketing practices represent (distressed, decomposed) overreaction to the marketers' self-embraced narrow view of their own social status (as maximiser of self-interest, profit, growth) that is largely irrelevant - even contradictory - to the crucial goals of society.
\end{abstract}

\section{Keywords}

authenticity, honesty, concern for other, ethical marketing, social status, macromarketing

Surprisingly, "normal" marketing discourse is largely silent with regard to the authenticity displayed when marketers engage in marketing. The lack of a comprehensive ethical discussion is staggering; it seems as though the notions of authenticity, honesty, and sincerity in market behavior, and the related notion of genuineness in marketing practice, are antithetical to marketing. Although much research examines how to manipulate various cues to make brands look more authentic or how to respond to consumers' authenticity expectations (Beverland 2009; Beverland, Lindgreen, and Vink 2008; Grayson and Martinec 2004; Rose and Wood 2005), these studies due to their micromarketing orientation completely miss the essence of the issue. To elaborate, brand authenticity research has almost totally a micromarketing agenda, which is expressed in its focus on how to employ the "authenticity" concept to maximize firm side, market actors' self-interests. This perspective is not what we are concerned with here. By taking a macromarketing perspective, we focus on why and how managers should instill authenticity into marketing practices rather than on how to manipulate/exploit consumers' authenticity predilections in order to sell more. We see authenticity as a mode, not a means, for efficient and effective marketing.

To clarify, our investigation is not about identifying factors that might "significantly" influence consumers' authenticity perceptions so that managers could successfully manipulate market encounters to their benefit. Setting it apart from micromarketing research, the purpose of this investigation is to call researchers towards investigating how marketers should (and also could) sincerely invest their passion, effort, and aspirations (their humanity) in sincere concern for another (benefiting oneself by means of benefiting the other). This notion is the real essence of the marketing orientation, albeit uniquely understood from the macromarketing perspective. In particular, we would like to explain why marketers should respond to citizens' quest for authenticity in the marketplace by a means of constructing authentic existence and practices. This implies provisioning society in a harmonious way while avoiding excessive environmental, social, cultural, and intergenerational harm that can result from over-emphasis on constructing hyperreal experiences.

Authenticity is now and has always been in demand - it is not a new discovery. Investigations show that consumers actively seek authentic businesses, brands, places, and persons (Alexander 2009; Beverland 2009; Cohen 1988; Holt 2002). General pursuit for authenticity in the marketplace reflects society's general macromarketing sensitivity. To become authentic (or real) a business must genuinely promote the common good, that is, community welfare and mutually beneficial outcomes. Note that for lay persons, words such as real, authentic, or genuine, might have different meanings in different contexts. Specifically, the word "authentic" might carry a barely perceptible denotation of harmonious existence in society. However, our scrutiny of the authenticity literature leads us to believe that most authenticity perceptions refer to a single

\footnotetext{
'Eastern Institute of Technology, New Zealand

${ }^{2}$ The Waikato Management School, University of Waikato, New Zealand

${ }^{3}$ University of Otago, New Zealand
}

\section{Corresponding Author:}

Djavlonbek Kadirov, School of Business, Faculty of Applied Science, Business and Computing, Eastern Institute of Technology, Private Bag 1201, Hawke's Bay Mail Centre, Napier, 4I42, New Zealand.

Email: dkadirov@eit.ac.nz 
latent assumption about the marketer's or brand's character: to be able to offer authentic products and services, marketers (or firms) must be an organic part of society. They should genuinely perform their function of provisioning without presence; they should not aspire to be seen as more than this; they should not manipulate citizens and systems for the sake of disproportionate growth or profit. These firms are marketing the way that Breyer (1934, p. 192) described it:

Marketing is not primarily a means of garnering profit for individuals. It is, in the larger, more vital sense, an economic instrument used to accomplish indispensible social ends. Under a system of division of labor there must be some vehicle to move the surplus production of specialists to deficit areas if society is to support itself. This is the social objective of marketing.

Furthermore, we argue that real (authentic) businesses are genuine participants of marketing systems in the sense that they can effectively satisfy (authentic) consumer needs while avoiding coercive tactics. By the same token, an inauthentic business is like a tumor, a cancerous attachment, which is indistinguishable from societal fabric yet feeds on society by externalizing its costs. Inauthentic businesses tend to create long-term harm to both individual consumers and society as a whole, and also, ultimately, themselves. We submit that inauthentic businesses use micro-marketing excessively. This behavior not only functions as a veneer to mask an extreme passion for profit over anything else, but also reveals these businesses' fundamental misconception about their own status in society.

\section{Seeking Authenticity}

Brown, Sherry, and Kozinets (2003, p. 21) declare that the search for authenticity will soon become "one of the cornerstones of contemporary marketing." Researchers have increasingly realized that consumers, participants in the general tendency to quest for authenticity in society, are increasingly seeking authentic experiences that are enabled by relevant and responsible market offerings and market agents (Alexander 2009; Beverland and Farrelly 2010; Holt 2002; Peñaloza 2000; Seeman 1966). The quest for authenticity is well documented in a wide range of marketing settings: luxury products (Beverland 2005a, 2005b), mundane objects and mass marketed products (Beverland and Farrelly 2010), reality television (Rose and Wood 2005), and tourism sites (Cohen 1988; Grayson and Martinec 2004; MacCannell 1973).

Authenticity has become an acute problem related to marketers and marketing in recent years, and specific sociocultural conditions undergird the phenomenon. In Holt's (2002) opinion, the quest for authenticity is a natural reaction of the consumer to mainstream societal mores of modernity. Holt argued that the rise of modern U.S. consumer culture circa 1920s-1960 s was underpinned by the growth of a wealthy middle class, the introduction of radio and television, and suburbanization. These factors enabled marketers to successfully engineer a standardized consumer culture. To counteract this tendency, the postmodern consumer culture (developed after the 1960 s) was driven by non-conformist experimentation based on alternative ways of existence and seeing "the self as a work under construction" (Holt 2002, p. 82). As experimenting with alternative lifestyles and personal freedom have increased, brands that still attempt to impose authority on consumer culture have gradually lost ground and brands which supported and enabled postmodern aspirations have grown in popularity. Holt observed that people were increasingly becoming attuned to the undesirability of significant control, exercised by marketers and marketing, over their personal lives and identities. The main issue with coercive modern marketing techniques that troubled many was that such tactics were completely antithetical to the American ideal of individual freedom, supremacy, and sovereignty (Holt 2002). Thus, we think that Holt's analysis alludes to inadequate application of the marketing concept (i.e. marketer usurpation of an entrusted role of societal provisioning) as a reason for growing consumer disenchantment with adversarial commerce and thus demand for authenticity (see also Zuboff and Maxmin 2002).

Along similar lines, Arnould and Price (2000) indicate that postmodernity, "an economy dominated by [micro] marketing" (p. 140), is characterized by the loss of a sense of community. The authors show that postmodern market conditions such as globalization, deterritorialization, and hyperreality have created a situation where a person experiences life as empty, meaningless, and fragmented. As a result, a strong urgency arises to bring the sense of community back to personal life. Hence, more and more consumers resort to authenticating acts, that is, practices that help them experience themselves and others as real. In addition, market players and institutions wholeheartedly embraced postmodern realities that aggravated consumer uncertainty and risk (Brown 1995b). Therefore, we believe that authenticating acts observed by Arnould and Price (2000) represent one of consumers' vital concerns in the contemporary marketplace.

In addition, Beverland and Farrelly (2010) demonstrated that authenticity sensitivities in the marketplace spring from three interrelated consumer goals: sovereignty, connection to the (real) other, and morality. While consumers strive to uphold personal control over their consumption and see their own sovereignty as an important element of market participation, they would like to be connected to real people (whether marketers or fellow consumers) in real (i.e. unstaged) contexts. Beverland and Farrelly (2010) show that consumers strive to connect with sincere people who own or represent brands. Also, consumers want to closely experience and observe non-commercial passion, disinterestedness, and dedication to a profession exhibited by others in real life situations, specifically in marketing contexts. Last but not least, the authors show that consumers care about universal virtues that enable them to uphold best moral practices such as honesty, selflessness, and non-materialism.

In this we see the quest for authenticity in markets that is underscored by consumer aspirations to become someone who does not fit the neoclassical depiction of economic man (homo economicus) - a narrowly self-interested utility maximizer (Brockway 1995; Henderson 1978). Here, we realize that consumers stand out as active creators rather than being passive 
recipient utility maximizers. Homo reciprocans is motivated by the desire to co-operate and improve the environment. These consumners aspire to exercise sovereignty and struggle to free themselves from imposed "consumption codes" (Murray and Ozanne 1991). Research shows that most consumers reflexively and creatively resist marketer imposed meanings (Holt 2002). The view of the predictable consumer who is driven to maximize self-interest, obsessively pursue desires, and mechanically respond to marketing stimuli appears to be merely an abstraction from the social reality, or a simplistic illusion, that has been very convenient for behavioral modeling purposes (Daly, Cobb, and Cobb 1994). In fact, the profound marketing paradox is that sovereignty is promised to consumers by the virtue of the marketing concept, but at the same time denied by manipulative marketing practices (Brownlie and Saren 1992). Moreover, consumers are not downright egoists (Brockway 1995). Undoubtedly, people are naturally interested in their personal well-being. However, they are also interested in the wellbeing, progress, and happiness of others (Daly, Cobb, and Cobb 1994), as a sense of relationship and community is at the heart of being human (Arnould and Price 2000).

\section{Authenticity Explained}

Authenticity is a complex notion (Beverland 2009) with different and in some instances contrasting definitions of the concept in the literature. Although the dictionary definition relates "authenticity" to genuineness, sincerity, truth, and reality, these words can have different meanings to different people in different settings (Grayson and Martinec 2004). Nevertheless, Beverland and Farrelly (2010) say that “... despite the multiplicity of terms and interpretations applied to authenticity, ultimately what is consistent across the literature is that authenticity encapsulates what is genuine, real, and/or true" (p. 839). Although the meanings of the notion "authenticity" used in marketing and/or consumption discourses are contextual and fluid, we believe that various explanations of this concept boil down to a single meta-idea: marketers' judgment about their own self-constructed status in society. Paradoxical micromanagerial marketing techniques that operate in opposition to the original marketing logic have left consumers wondering about whether market offerings are the product of marketers' self-selected intentionality (i.e. status) underscored by the pure profit motive, or in contrast, by genuine/sincere dedication to customer satisfaction. In other words, consumers are inclined to make a judgment about whether marketers' motivations are purely commercial versus communal or whether they are predominantly driven by economic self-interest over holistic community interest (some historians might invoke the authoritarian master-slave relationship to explain this). By shifting focus from authenticity being a product (brand) attribute to authenticity representing the marketer's condition and selfunderstanding, we move closer towards the existential definition of the concept (Detmer 2008; Heter 2006; Sartre 1992). This is not an easy claim to make. The following discussion will hopefully lend some weight to our thesis.
Beverland (2005) summarizes the literature along a continuum of degrees of ascribing authenticity to objects. At one of its extremes, authenticity is considered to be inherent in an object, while at the other extreme authenticity is considered to be the object's relation to other elements in the environment (e.g. place, time, history, tradition). In their recent research, Beverland and Farrelly (2010) argue that consumers do not see authenticity as an inherent attribute of a product. Rather consumers are shown to ascribe authenticity to what they observe in the behavior of the members of a firm that sponsors a brand.

In tourism research, for example, the problem of authenticity is explained in a straightforward way: tourism commoditizes the exposed areas of a community's life that have been governed by benign community-based (i.e. localized) market forces prior to commoditization and commercialization (Cohen 1988; MacCannell 1973). Local culture "for sale" is not authentic, rather it becomes a meaningless duplicate (or emulation, perhaps insincere) of what used to be real (Cohen 1988). To make matters worse, a second wave of inauthenticity hits tourism markets as marketers (including both foreigners and local members of society) expropriate and appropriate local resources stage authenticity in response to tourists' search for the real (MacCannell 1973). From this perspective, an authentic market offering is defined to be a good/service that has been made for personal or local community consumption. So it is the producer's intention that makes the product more or less authentic. Taking this idea to a more general marketing level, we see that this is what consumers demand from producers: market offerings must be the result of sincere actions where such sincerity should match the sincerity of making similar products for the self or close community members. The profit motive must not taint the process. Rather profit is the reward for authenticity in creating value. It is a matter of discerning means and end.

Grayson and Martinec (2004) introduce the concepts of indexical and iconic authenticity. A product is considered to be indexically authentic if it is the real thing, the original, something that is free of imitating or copying. Indexically authentic products have a real proven spatial and temporal link to sources (e.g. place, people, events) that produce authenticity. An example is cottage cheese made for local or own consumption in a particular farm following local small-scale production processes. Can Edam cheese, originally from the town of Edam in North Holland, be authentic when made in New Zealand? In contrast, a product is iconically authentic if it is very similar to what is perceived to be authentic. Here, "iconic" refers to similarity or closeness of the product to the perceived authentic original (Grayson and Martinec 2004). Back to the same example, the local farm's cottage cheese is iconically authentic if it is made for sale to distant communities following the same unique local production, recipe, and most importantly, the maker's sincere communal attitude.

In search for indexical and iconic cues to identify the drivers of authenticity, practitioners and researchers seem to miss the forest for the trees, that is, the "macro (big, whole) picture." They seem too preoccupied with authenticity cues, such as 
craftsmanship, tradition, performance quality and excellence, history, pedigree, and place (Beverland 2005, 2009; Grayson and Martinec 2004), while most of their rhetoric seems to be focused on objects rather than processes. They assume that if the marketer highlights or even fabricates and contrives a product's link to relevant cues, then the product is going to be perceived as (more) authentic. The irony here is that such fabrication (an insincere process) is thought to lead to an authentic product (an object). A number of examples given in the literature attest to marketer reliance on a great deal of fabrication including producer story telling, creating stylized accounts of actual historical events and personalities (Beverland 2005; Peñaloza 2000; Spring 2003). There is much concern about staged authenticity in tourism as well (MacCannell 1973). Marketers can certainly manipulate cues and consumer perceptions of authenticity to attain short-term effects (Beverland 2009). Indirectly, this is our concern here. We should be investigating the main underlying reasons for why some (though not all) indexical or iconic cues assume a higher status in the eye of consumers? The answer can be found in the arguments posited by tourism research. Authentic products are goods made for own or local small community consumption where no chrematistic (i.e. wealth extraction) agenda is the source of indexical authenticity. Similarly, at a more general level, products can be (iconically) authentic if they are created exactly following the original conditions and procedures that had a communal character and were free from the profit motive, but are sold in the market, even at a distance.

We believe that posited cues such as craftsmanship or production excellence (i.e. quality) are only as good as the producer's communal intention or communal conditions that drive a value-creation process. Objects become valuable if the process of creation is underlined by passion for excellence, commitment to craftsmanship, and selfless effort coupled with indifference to profit, growth or money hoarding. Holt (2002) states that

" . . . to be authentic, brands must be disinterested; they must be perceived as invented and disseminated by parties without an instrumental economic agenda, by people who are intrinsically motivated by their inherent [extra-market] value. Postmodern consumers perceive modern branding efforts to be inauthentic because they ooze with the commercial intent of their sponsors" (p. 83).

From a different perspective, existentialists explain authenticity through positing what authenticity is not (Detmer 2008; Sartre 1992; Seeman 1966). Existentialists do not use the authenticity concept to mean "being true to one's roots and heritage" (Heter 2006, p. 3). Neither does the concept mean one's success in conformity to historical, traditional, stereotypical assumptions or patterns. Existentialists contend that if an element of history or a particular tradition is fundamentally flawed, then sticking to one's history does not make an entity authentic (as viewed from the societal perspective).

Heter (2006) claims that the concept of authenticity is deeply linked to moral virtues; therefore researchers must always maintain its positive connotation. He further explains why something like "authentically evil" is impossible and states that terms like "authentic Nazi" are inherently paradoxical. From Heter's (2006) point of view one cannot be authentic and evil at the same time. In the marketing context, how plausible is the micro-marketing suggestion that a firm can be authentic while still sticking to the idea of the unabashed pursuit of selfinterest? Is "authentic Homo Economicus" possible?

According to Sartre (1992), the guru of existential philosophy, authenticity is the absence of inauthenticity, that is, one can only attain authenticity if he or she can avoid inauthenticity. For Sartre (1992), inauthenticity (which he calls bad faith) is latent self-deception based on a perception that the person is literally fixed to his or her occupational role. Hence, Sartre's philosophy demonstrates that authenticity and the view of the self (in society) are fundamentally linked. If one's view of the self is based on a wrong assumption or distinction, then the outcome of his or her behavior is going to be judged to be more or less inauthentic.

Building on Sartre's argument, Seeman (1966) notes that inauthenticity may arise when one is insecure about his or her status in social relationships. Inauthenticity refers to "the individual's over-reaction to the occupancy of a given status" (p. 68). For example, a black person may project an artificially cultured manner to prove anti-black stereotyping wrong. Similarly, Seeman's (1966) research showed that black children attach greater importance to the color of skin, thereby applying an "irrelevant status criterion." Seeman says that the concept "irrelevant" means undemonstrated. It is indemonstrable (or even ethically incorrect to consider) that a color of skin makes a person better or worse (e.g. cultured or uncultured). Hence, two problems give rise to cases of inauthenticity. First, people accept a given (possibly wrong) social status as crucial to the ways they live their lives and define themselves. Second, based on this perception of status, they act in a manner not natural to them (an overreaction), which signals inauthenticity.

Seeman (1966) makes a clear distinction between inauthenticity and other human acts such as dishonesty and dissimulation. In the case of dishonesty, a person is not self-deceived about his own status. A conman, for example, is certainly sure about his self-identity. Similarly, inauthenticity is not dissimulation, where what one says differs from what one does. Following this line of reasoning, existentialists agree that authenticity can be defined as lucid (open) consciousness about one's status (Detmer 2008; Sartre 1992; Seeman 1966).

\section{Authenticity of Marketing}

The marketing philosophy is a vision that is in need of authentic and sincere application (Brown 1995a; Varey 2010). Researchers note that marketing will remain an empty ideology if not applied sincerely in the marketplace (Brownlie and Saren 1992). Authentic marketing cannot be achieved if the marketer's passion is solely invested in making more money (for self or investors), while the marketing concept implies the passionate pursuit of the other's (consumer, stakeholders) interest as a means of attaining goals. This requires genuine commitment to creating solutions for the betterment of life. 
Table I. Authenticity Dialectics.

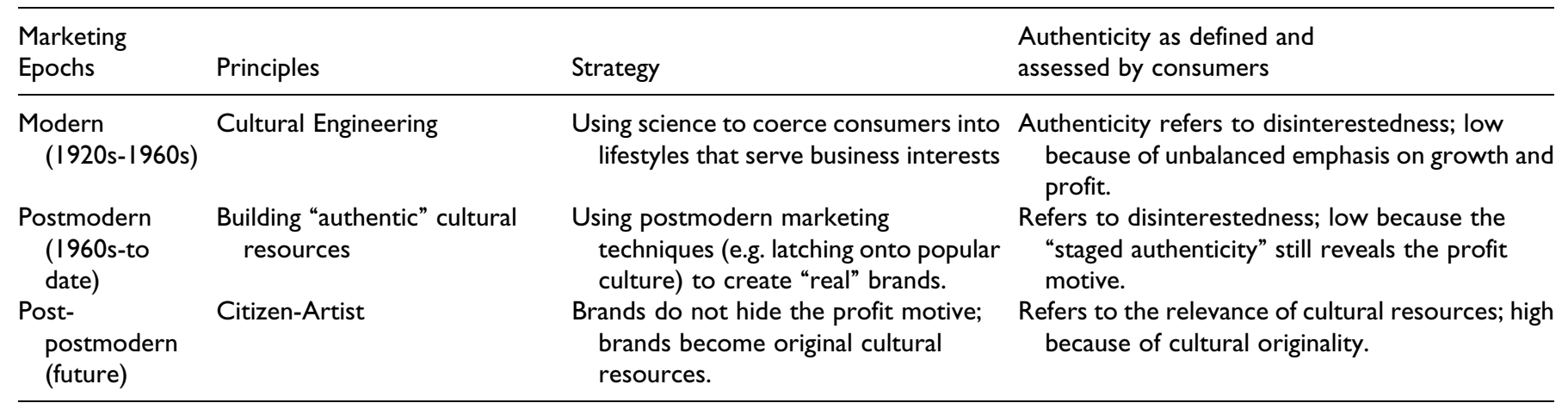

Source: Adapted from Holt (2002).

Ever since the $1950 \mathrm{~s}$, when Peter Drucker elevated the status of marketing to the paramount function of business, the resulting micromarketing ideology and idealization of the marketing concept has resulted in a "marketing conflagration" in both academia and practice (Brown 1995a). Thus, marketing as a unique system of societal provisioning has faced a profound conundrum. Whether we call it a crisis of representation or a macromarketing paradox deeply embedded in how the marketing concept relates to the ultimate rationale for a commercial enterprise, the essence of the conundrum is simple. To be marketing oriented, businesses must exhibit genuine concern for consumer satisfaction and well-being, while the neoclassical interpretation of ultimate marketing objectives, namely unlimited growth, profit-maximization, unchecked pursuit of self-interest, and rampant commercialization, do not really fit the proposed prescription and have profound negative effects (Kilbourne, McDonagh, and Prothero 1997; Varey 2010). Although many managers claim to embrace the marketing orientation that is premised upon giving precedence to consumer interests over anything else, few companies appear to have sincerely implemented it. Rather, much marketing still involves manipulation and creation of consumer demand instead of expected anticipation and satisfaction of existing real needs (Brownlie and Saren 1992).

Genuineness is signaled via the directedness of human passion. As common citizens (in both marketing and other occupations) realize that most marketing passion is in fact invested in self-interest (i.e. meeting company needs first), and self-interest is in conflict with other (e.g. consumer, community-driven) goals more often than not, they tend to grow more skeptical about the genuineness of brands and corporate claims that keep driving a standard marketing logic home while pretending to be sincerely concerned with consumer and societal interests. Hence, marketing practitioners by uncritically adopting neo-classical prerogatives have, in most cases unwittingly, cornered themselves in a self-perpetual paradox which is not only underlined by other-deception, but also by selfdeception (Woodall 2012).

It needs to be emphasized that only a holistic (macro) analysis of marketing development is more likely to detect a profound link between marketing and authenticity. Holt's (2002) analysis of the dialectical evolution of market culture is one of the exemplary studies. By studying how marketing has dialectically evolved in response to consumers' authenticity demands, Holt concludes that "authentic marketing" is the marketing of the future (see Table 1). In his study, Holt offers an operational definition of authenticity: the concept refers to consumers' judgment of the brand's distance from the profit motive. In other words, authenticity means disinterestedness (i.e. opposite of self-interest).

Holt argues that in the modern marketing era circa 1920s1960 s marketers were implicitly accepted as cultural experts and granted "market" authority to genuinely direct people toward success, happiness, and satisfactory lifestyle as per the marketing concept. As the profit drive has resulted in excessive competitiveness, imitation, mimetic action, and the use of science for manipulative influence, consumers have become disillusioned with the supposedly noble aspirations of marketers. Holt argues further that marketers, realizing the extent of consumer discontent and citizens' detest of the breach of an implicit social contract, have started using postmodern marketing techniques that have helped to portray brands and marketers as "authentic." As more and more companies jumped on the bandwagon of crafting (staging) authenticity (still predominantly to so-called "audiences"), it has become evident to consumers that the artifice of claimed authenticity - including employees posing as customers writing positive comments about products in blogs and newspapers - is simply a mask that conceals the thirst for more profits.

Marketers got it wrong again. Their over-reaction to a desired status made them look ever more inauthentic. Besides, consumer activist and countercultural movements were on watch: their "sharp eye" could still penetrate the veneer of carefully crafted "genuineness" that has been put in the service of commercialism and profiteering (Holt 2002). In envisioning the future, Holt hopes a time will come when all businesses openly admit their profit drive and will seek to earn their reward by offering brands as original cultural resources that uniquely contribute to consumer identity projects. In expressing this hope, Holt stops short of challenging the status quo of self-interest in the modern market systems. Rather, he believes that if everyone realized that businesses are there to 
primarily pursue self-interest, then "the standard of disinterestedness" is going to be supplanted by the judgment of original cultural contribution. In time, we anticipate, solely self-interested businesses will not be sustainably patronized because they do not have others' needs at heart (Varey 2011).

\section{Discussion: Micromarketing and Inauthenticity}

Based on the preceding discussion, we distinguish two sources of inauthenticity:

Direct inauthenticity. Managers wholeheartedly embrace a narrow view of their own role in society, one enforced by existing institutional foundations (Kilbourne, McDonagh, and Prothero 1997). Instead of seeing themselves as "provisioners," marketers construct a neo-classically biased self-identity, a cynical professionalism morally obliged to "generate" profit at any cost, including price scalping and tax avoidance. This is an incorrect criterion for self-assessment. Excellence in profit generation or pursuing self-interest does not make one superior to others any more than does skin color (Seeman 1966). Research consistently shows that the pursuit of self-interest, and the outcome of this process in the form of excess material wealth, will guarantee neither professional self-fulfillment nor ultimate happiness.

Self-referential inauthenticity. Marketers realize that the focus on self-interest is not what consumers or society want from brands, businesses, and managers. Consumers demand authenticity; they value marketing that genuinely distances itself from the profit motive and represents consumer in company decision-making. As the marketing orientation implies absolute dedication to the cause of the consumer, marketers tend to experience a profound conundrum leading to latent nervousness about the conflict between own assumed status and what is required from them. Such anxiety is exhibited in marketers' involvement in manipulative micromarketing practices that focus on becoming "real." The paradox of self-reference is obvious here: marketing practices initiated to create a veneer authenticity signal at a macro level that these practices are inauthentic. No wonder that some modern stealth and covert marketing techniques are directed at misleading consumers about the true identity of information sponsors.

We believe that micromarketing as a general phenomenon in society is the outcome of marketers' over-reaction to their assumed irrelevant status in society. Micromarketing practices are simply natural patterns of behavior that result from introduced biases of understanding marketing from the neoclassical perspective.

At a more general level, society has to decide what is acceptable. No longer is it ethically adequate to claim that "it's only business." A balanced stance on quality of life in terms of resource use and outcomes will not allow dog-eat-dog and profit-at-any price thinking, nor will it allow externalities and "we can't afford to be responsible to each other" justifications. The foundational question is what do we want marketing to do for us individually and communally?

\section{Declaration of Conflicting Interests}

The author(s) declared no potential conflicts of interest with respect to the research, authorship, and/or publication of this article.

\section{Funding}

The author(s) received no financial support for the research, authorship, and/or publication of this article.

\section{Note}

1. Marketing is the process of transforming or changing an organization to have what people will buy - the organization is influenced by the needs and wants of the market and the consumer is not unreasonably influenced by the desires of the seller.

\section{References}

Alexander, Nicholas (2009), "Brand Authentication: Creating and Maintaining Brand Auras," European Journal of Marketing, 43 (3/4), 551-562.

Arnould, Eric J. and Linda L. Price, (2000), "Authenticating Acts and Authoritative Performances: Questing for Self and Community," in The Why of Consumption: Contemporary Perspectives on Consumer Motives, Goals, and Desires, S. Ratneshwar, David Glen Mick, and Cynthia Huffman, eds., London, UK: Routledge, 140-163.

Beverland, Michael B. (2005), "Crafting Brand Authenticity: The Case of Luxury Wines," Journal of Management Studies, 42 (5), 1003-1029.

Beverland, Michael B. (2009), Building Brand Authenticity: Seven Habits of Iconic Brands. Houndmills, UK: Palgrave Macmillan.

Beverland, Michael B. and Francis J. Farrelly (2010), “The Quest For Authenticity in Consumption: Consumers' Purposive Choice of Authentic Cues To Shape Experienced Outcomes," Journal of Consumer Research, 36 (5), 838-856.

Beverland, Michael B. Adam Lindgreen, and Michiel W. Vink (2008), "Projecting Authenticity Through Advertising: Consumer Judgments of Advertisers' Claims," Journal of Advertising, 37 (1), 5-15.

Breyer, Ralph (1934), The Marketing Institution. New York: McGraw-Hill.

Brockway, George P. (1995), The End of Economic Man: Principles of Any Future Economics. New York: WW Norton and Company.

Brown, Stephen (1995a), "Life Begins at 40?: Further Thoughts on Marketing's 'Mid-life Crisis'," Marketing Intelligence and Planning, 13 (1), 4-17.

Brown, Stephen (1995b), Postmodern Marketing. London, UK: Routledge.

Brown, Stephen John F. Sherry Jr., and Robert V. Kozinets (2003), "Teaching Old Brands New Tricks: Retro Branding and the Revival of Brand Meaning," Journal of Marketing, 67 (3), 19-33.

Brownlie, Douglas and Michael Saren (1992), "The Four Ps of the Marketing Concept: Prescriptive, Polemical, Permanent and Problematical," European Journal of Marketing, 26 (4), 34-48.

Cohen, Erik (1988), "Authenticity and Commoditization in Tourism," Annals of Tourism Research, 15 (3), 371-386.

Daly, Herman E. John B. Cobb, and Clifford Cobb (1994), For the Common Good: Redirecting the Economy Toward Community, the Environment, and a Sustainable Future, Boston: Beacon Press. 
Detmer, David (2008), Sartre Explained: From Bad Faith to Authenticity, Chicago: Carus Publishing Company.

Grayson, Kent and Radan Martinec (2004), "Consumer Perceptions of Iconicity and Indexicality and their Influence on Assessments of Authentic Market Offerings," Journal of Consumer Research, 31 (2), 296-312.

Henderson, Hazel (1978), Creating Alternative Futures: The End of Economics. West Hartford, CT: Kumarian Press.

Heter, T. Storm (2006), Sartre's Ethics of Engagement: Authenticity and Civic Virture. London: Continuum.

Holt, Douglas B. (2002), "Why Do Brands Cause Trouble? A Dialectical Theory of Consumer Culture and Branding," Journal of Consumer Research, 29 (1), 70-90.

Kilbourne, William E. Pierre McDonagh, and Andrea Prothero (1997), "Sustainable Consumption and the Quality of Life: A Macromarketing Challenge to the Dominant Social Paradigm," Journal of Macromarketing, 17 (1), 4-21.

MacCannell, Dean (1973), "Staged Authenticity: Arrangements of Social Space in Tourist Settings," American Journal of Sociology, 79 (3), 589-603.

Murray, Jeff B. and Julie L. Ozanne, (1991), "The Critical Imagination: Emancipatory Interests in Consumer Research," Journal of Consumer Research, 18 (2), 129-144.

Peñaloza, Lisa (2000), “The Commodification of the American West: Marketers' Production of Cultural Meanings at the Trade Show," Journal of Marketing, 64 (4), 82-109.

Rose, Randall L. and Stacy L. Wood, (2005), "Paradox and the Consumption of Authenticity through Reality Television," Journal of Consumer Research, 32 (2), 284-296.

Sartre, Jean Paul (1992), Being and Nothingness: A Phenomenological Essay on Ontology. New York: Washington Square Press.

Seeman, Melvin (1966), "Status and Identity: The Problem of Inauthenticity," Pacific Sociological Review, 9 (2), 67-73.

Spring, Joel H. (2003), Educating the Consumer-citizen: A History of the Marriage of Schools, Advertising, and Media, Mahwah, NJ: Lawrence Erlbaum.
Varey, Richard J. (2010), "Marketing Means and Ends for a Sustainable Society: A Welfare Agenda for Transformative Change," Journal of Macromarketing, 30 (2), 112-126.

Varey, Richard J. (2011), “A Sustainable Society Logic for Marketing," Social Business 1 (1), 69-83.

Woodall, Tony (2012), "Driven to Excess? Linking Calling, Character and the (Mis) Behaviour of Marketers," Marketing Theory, 12 (2), 173-191.

Zuboff, Shoshana and James Maxmin (2002), The Support Economy: Why Corporations are Failing Individuals and the Next Episode of Capitalism. New York: Viking Books/Penguin Books.

\section{Author Biographies}

Djavlonbek Kadirov is a senior lecturer at the Eastern Institute of Technology, New Zealand. He received an M.Sc. in Marketing from the University of Salford, and a Ph.D. in Marketing from the University of Waikato. His research interests include macromarketing, marketing systems, marketing and society, sustainable marketing, and (in)authenticity. His research has appeared in journals such as the Journal of Macromarketing, Consumption Markets \& Culture, Journal of Customer Behaviour, and Journal of Research for Consumers.

Richard J. Varey is Professor of Marketing at The Waikato Management School, New Zealand. His scholarly project is "Marketing in and for sustainable society." He co-edited Internal Marketing: Directions for Management (Routledge), edited two editions of New Zealand Law for Marketers (LexisNexis), and authored Marketing Communication: Principles and Practice (Routledge) and Relationship Marketing: Dialogue and Networks in the E-Commerce Era (Wiley). His new edited book is Humanistic Marketing (Palgrave Macmillan).

Ben Wooliscroft is a Senior Lecturer in Marketing in the School of Business, University of Otago, Dunedin, New Zealand, where he was educated. His research centers in the interaction between marketing and society. His current research addresses sustainability, personal transportation and ethical consumption. 